\section{Sex, Sin, and Science: A History of Syphilis in America}

\author{
John Parascandola
}

Praeger Publishers, Santa Barbara, CA, USA, 2008

ISBN-10: 0275994309

ISBN-13: 978-0275994303

Pages: 224; Price: US $\$ 49.95$

At of end his book, John Parascandola writes, "It is my hope that the reader ... acquired a broader appreciation of disease as a social as well as a medical construct and of the way in which social and cultural factors influence our understanding of and reaction to any given disease." The social context of syphilis is nicely summarized by the title, Sex, Sin, and Science: A History of Syphilis in America. Because syphilis is sexually transmitted, it is often considered as a moral issue, and thus people who have syphilis have sinned. This perception is both absurd and insightful.

Parascandola's history of syphilis is compelling from the beginning. "Because many believed that the disease first made its appearance in the French troops besieging Naples, it was often called (especially by the Italians) morbus gallicus ('French disease') ... The French, on the other hand, preferred to call it the 'Neapolitan disease' blaming it on the city of Naples."

Syphilis was so sinful that it could not be discussed by name. "This continued hesitancy to discuss sexual matters is reflected in the terminology used in newspapers and other public media of the early twentieth century." "Social evil" meant prostitution. Syphilis and gonorrhea were "social diseases," and the effort to combat them was the "social hygiene" movement. We learn that in 1911 California became the first state to require physicians to report cases of venereal disease and that, to assure confidentiality, reporting was done by number rather than by name.

Some of those involved in the social hygiene movement were more interested in preventing sex than in preventing disease. A Public Health Service (PHS) advisory committee recommended changing an educational film so that "some attention be given to the influence of moral standards on the spread of disease' because if no reference was made to moral issues, it might appear to some that the PHS was "condoning sexual promiscuity."”

There was fear that penicillin might offer "complete freedom to indulge in licentiousness..." or "if extramarital sex did not lead to significant illness, only a 'few intangibles of the spirit' would remain to guide people into moral paths." Parascandola notes, "Social hygienists had always been at least as interested in moral as in health issues, and so their fight would not end with the defeat of venereal disease."

Parascandola's book informs readers that in 1953, "the Eisenhower administration proposed eliminating the PHS venereal disease program because its job was essentially done." But syphilis came back, along with gonorrhea, herpes, chlamydia, and AIDS.

There is considerable scientific evidence that HIV causes AIDS. Nonetheless, just as with syphilis, others think the cause is sin. Absurd. Yet the social construct Parascandola describes remains so pervasive that it continues to affect us all.

\section{Thomas A. Peterman}

Author affiliation: Centers for Disease Control and Prevention, Atlanta, Georgia, USA

DOI: 10.3201/eid1506.090308

Address for correspondence: Thomas A. Peterman, Centers for Disease Control and Prevention, 1600 Clifton Rd NE, Mailstop E02, Atlanta, GA 30333, USA; email: tpeterman@ cdc.gov

\section{Novel and Re-emerging Respiratory Viral Diseases: Novartis Foundation Symposium 290}

Gregory Bock and Jamie Goode, editors

John Wiley \& Sons, Ltd, Chichester, UK, 2008

ISBN: 978-0-470-06538-9

Pages: 174; Price: US $\$ 170.00$

This slim booklet, the product of a Novartis Foundation symposium held April 23-27, 2007, at Singapore's Institute of Molecular and Cell Biology, primarily highlights scientific issues concerning influenza and severe acute respiratory syndrome (SARS). The booklet comprises a mere 12 chapters of about 12 pages each of reports presented and discussed by only 29 participants. This may be its strengththe book's usefulness derives from its focus on only 2 diseases covered by multidisciplinary participants in a cross-cutting fashion and relative depth.

The book contains little new material. Rather, the chapters are brief but state-of-the-art reviews that, perhaps surprisingly, fit together well. For example, Gabriele Neumann and Yoshi Kawaoka discuss broad aspects of pandemic influenza; other scientists discuss the transmission and pathogenicity of influenza viruses A (H5N1), their genetic and antigenic characteristics, general antigenic associations between human and swine viruses, and the molecular aspects of viral membrane fusion. Reading for less than half an hour yields an awareness of many key issues surrounding influenza emergence, well reviewed by international experts. The chapters about SARS are equally strong, with presentations by teams from both Taiwan and Singapore highlighting their real-world experiences in an epidemic 